\title{
Te Pikinga ki Runga Raising Possibilities
}

\section{SONJA MACFARLANE}

\section{KEY POINTS}

- Te Pikinga ki Runga: Raising Possibilities is based on the human-rights principles within the Treaty of Waitangi.

- Under the principle of partnership, effective partnerships with whānau are key.

- Under the principle of protection, the framework envisages a strengths-based and holistic approach to student wellbeing. This is based on four domains-hononga (relational aspects), hinengaro (psychological aspects), tinana (physical aspects) and mana motuhake (self-concept).

- $\quad$ The four domains are further broken down into 12 subdimensions, in a grid affectionately named Te Huia, along with reflective questions to aid practical application of the framework.

- Under the principle of participation, the framework develops key competency components that relate to The New Zealand Curriculum's key competencies, Māori cultural constructs about pedagogy and development, and Effective Interventions for Behavioural Challenges concepts. 


\section{This article presents Te Pikinga ki Runga: Raising Possibilities, a framework for teachers and special education practitioners working with Māori students who are presented with challenges. It draws on the work of leading Māori educationalists to offer a kaupapa Māori approach that can be applied in practice.}

\section{Background}

$\mathrm{T}$

This paper explores a culturally pragmatic kaupapa

Māori approach to assessment, analysis and

programme planning for teachers and special

education practitioners working in classrooms with students who are presenting with challenges. Three imperatives drove the development of this project: that practice should be evidence-based and relevant; that the principles of sociocultural theory embodied in the work of a number of leading Māori educationalists would be a logical place from which to draw significant evidence; and that in te ao Māori, the Māori world, intervention approaches require a direct acknowledgement of the contexts from within which individuals and teams work. This project draws from these three imperatives to offer an education-specific framework for working with Māori students and their whānau, Te Pikinga ki Runga: Raising Possibilities.

\section{Introduction}

Psychological assessment constitutes a major function of applied professional services. As part of the wider process of understanding and making meaning it allows psychologists and other professionals to make relevant decisions for devising programmes that aim to achieve better outcomes, usually for individuals experiencing difficulties in their lives. However, psychology has traditionally been a discipline based on Western paradigms of thinking and theorising (Macfarlane \& Macfarlane, 2008).

There are concerns about clinically dominated approaches within mainstream and special education identification, assessment and programme planning. Further, some have criticised the use of such psychological assessment protocols in cultures in which these protocols seem to lack compatibility (Hambleton, 2001; van de Vijver \& Hambleton, 1996). Questions are also continually being raised about the assumption that using international evidence about assessment will result in the best possible outcomes for all young people in New Zealand (Blampied, 1999; Evans, Fitzgerald, Harvey, \& Herbert, 2008; Herbert, 2002; Macfarlane, 1998; Macfarlane, Glynn, Grace, Penetito, \& Bateman, 2008; Meyer, 2003; Nikora, 2007). According to Macfarlane, Blampied and Macfarlane (2009), there is a critical need to rethink and reposition mainstream and special educational assessment approaches so as to ensure that such approaches are the best "fit" for-and are able to collate the most relevant information about- those who are being assessed.

\section{Theorising from within a Māori world view}

Te Pikinga ki Runga is an assessment, analysis and programme-planning framework specifically intended to guide education professionals in their interactions when working with Māori students and their whānau. The framework was originally developed to guide work with those Māori students who are exhibiting severe and challenging behaviours in education settings and are therefore at risk of educational underachievement-or even failure. However, it has become increasingly clear that Te Pikinga ki Runga is able to be implemented by education practitioners (including teachers) for Māori students who are exhibiting mild-to-moderate learning and/or behavioural challenges in education settings.

It needs to be stated that the framework is not a recipe that promises to "fix" the particular situation or individual; rather, it is a framework that is intended to raise the possibilities for these youngsters as they grapple with learning, socialisation, peer interactions and-in some cases - the very essence of their own identity.

In response to these realities, it was decided that the intervention strategies that may result from applying Te Pikinga ki Runga should be guided by three fundamental human-rights principles: those that sit at the very heart of our bicultural society in Aotearoa New Zealand-within the Treaty of Waitangi. 


\section{MĀORI ACHIEVEMENT}

\section{The Treaty of Waitangi}

The Treaty of Waitangi underpins the Ministry of Education's 2008 Ka Hikitia: Managing for Success: The Māori Education Strategy 2008-2012. In this strategic document it is stated that:

The Treaty of Waitangi is a valued relationship management tool, symbolic of our past and central to our future. (p. 9)

The treaty is also reflected in The New Zealand Curriculum (Ministry of Education, 2007), which states that:

The New Zealand Curriculum ... will help schools give effect to the partnership that is at the core of our nation's founding document, Te Tiriti o Waitangi/The Treaty of Waitangi. (p. 3)

Further, the Ministry of Education, Special Education (2006) states that the Specialist Service Standards "have been developed through a process that reflects the principles of Te Tiriti o Waitangi” (p. 6).

Given the strength and intention of these three statements, it was a natural progression to considering how the Treaty of Waitangi might be operationalised as a practice framework for education practitioners. In order to understand how the Treaty of Waitangi guided the development of Te Pikinga ki Runga, it is necessary to explore some of the key notions that reside within each of the three treaty principles: those of partnership, protection and participation.

\section{Principle 1: Partnership_partnering and engaging with whānau/family}

Under the treaty principle of partnership, whānau is at the core. International and national research alike both highlight the critical importance of education professionals building and maintaining positive relationships with whānau/family and caregivers. In Aotearoa New Zealand, we now recognise that effective engagement and consultation with the whānau/family (and the cultural community) is a crucial component for educational decision making and for education outcomes achieved by students (Bevan-Brown, 2001, 2003; Kingi \& Durie, 2000; Macfarlane, 2005).

But what does effective partnering look like? Glynn, Berryman, Walker, Reweti and O'Brien (2001) describe a "life partnership analogy", which declares that what we know and understand about conducting personal partnerships in life can guide us in establishing effective working partnerships with others. The analogy highlights how destructive outcomes can occur within relationships where one partner holds a far more powerful and dominant position than the other. Effective partnering with whānau therefore needs to consider how power is shared and balanced (Bishop \& Glynn, 1999).
Under the heading of "Huakina Mai" (opening doorways), Te Pikinga ki Runga includes a range of dimensions that are necessary in responding to the Treaty of Waitangi principle of partnership.

2. Principle 2: Protection_-protecting and enhancing the wellbeing, identity and selfconcept of the tamaiti (child)

Under the treaty principle of protection, the tamaiti is at the core. This principle acknowledges the importance of protecting and enhancing student self-concept and cultural identity by utilising strengths-based and holistic approaches to overall health and wellbeing.

The Ministry of Education's (2008) Māori education strategy, Ka Hikitia: Managing for Success, espouses the notion of moving from focusing on deficit to focusing on potential when seeking to be responsive to Māori students. This strategic document reiterates the importance of "realising Māori potential" by focusing on strengths.

There is a range of holistic wellbeing frameworks currently available for working with Māori in both education and health. These frameworks include: Rose Pere's (1991) framework, Te Wheke; the Ministry of Education's (1996) early childhood curriculum, Te Whāriki; Irwin's (1984) triangle, based on the elements of mind, body and spirit; Durie's (1994) Te Whare Tapa Whā; and Durie's (1999) Te Pae Mahutonga.

Research undertaken by Durie in 1998 confirms the belief that Māori who are more secure in their own cultural identity and self-concept have higher educational aspirations and outcomes than those who are less secure. Tajfel and Turner (1986) assert that self-concept comprises two key components. The first component is personal identity, which covers such characteristics as one's own particular talents or abilities. The second component is social identity, which emanates out of one's own awareness of personal membership in a particular social group, and the emotional significance that one places on one's own involvement in that group (Tajfel, 1981).

Drawing on all of the above notions, Te Pikinga ki Runga uses four specific holistic domains in its educational approach to wholeness and wellbeing (summarised in Figure 1). While several of the frameworks noted above include "spirituality" as a key element, Māori and non-Māori alike have challenged whether education practitioners would be able to respond effectively and authentically to the Māori concept of "wairua" or spirituality (Durie, 1994) within the context of education.

It was therefore decided that three domains (hononga, hinengaro and tinana-relational aspects, psychological aspects and physical aspects) would comprise the core 


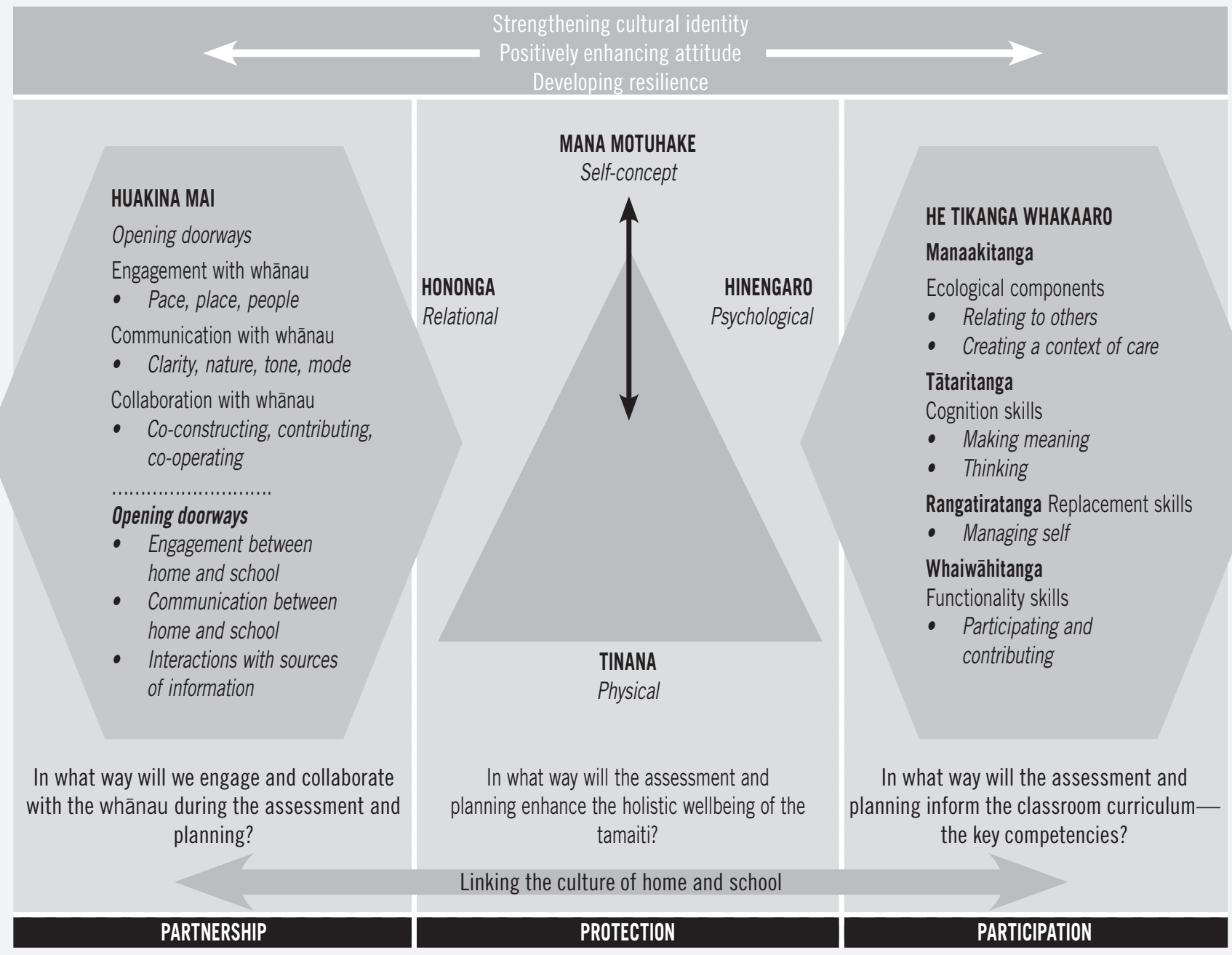

(Copyright (C) 2008 by S \& A Macfarlane)

configuration - that of a triangle — with an encompassing and emanating fourth domain (mana motuhake-selfconcept), which is both integral to, and a resultant outcome of, all four domains working together.

In order to help practitioners to "unpack" each of the four domains, each one was broken down into three subdimensions (resulting in 12 dimensions in total—see Table 1). The dimensions grid is affectionately referred to as Te Huia - a name that was gifted by a kuia who participated in a seminar where Te Pikinga ki Runga was initially shared. She saw that the 12 dimensions of the grid are like the 12 prized tail feathers of the huia; and that if we don't protect or care for these (her metaphor for the tamaiti), they are also at risk of extinction.

The Te Huia dimension grid is further supported by a set of reflective prompt questions that practitioners are able to consider when implementing the treaty principle of protection.
3. Principle 3: Participation-Enhancing the classroom curriculum to support presence, participation and learning for the tamaiti

Under the treaty principle of participation, the tamaiti-as a learner in, member of and contributor to the classroom ecology - is at the core. This principle is responsive to The New Zealand Curriculum's key competencies (Ministry of Education, 2007) as essential vehicles for enriching the classroom ecology, pedagogy and curriculum, and therefore igniting and eliciting student participation and learning (Brewerton, 2004).

The competency areas are:

- thinking

- making meaning

- relating to others

- managing self

- participating and contributing. 


\section{MĀORI ACHIEVEMENT}

TABLE 1 TE PIKINGA KI RUNGA: TE HUIA: PROTECTING THE WELLBEING OF THE TAMAITI

(Adapted from Kingi and Durie, 2000)

\begin{tabular}{|c|c|c|c|c|}
\hline & \multicolumn{4}{|c|}{ Domains } \\
\hline & $\begin{array}{l}\text { Hononga: } \\
\text { (Relational aspects) }\end{array}$ & $\begin{array}{l}\text { Hinengaro: } \\
\text { (Psychological aspects) }\end{array}$ & $\begin{array}{l}\text { Tinana: } \\
\text { (Physical aspects) }\end{array}$ & $\begin{array}{l}\text { Mana Motuhake: } \\
\text { (Self-concept) }\end{array}$ \\
\hline \multirow{3}{*}{$\frac{\text { D }}{\frac{0}{0}}$} & $\begin{array}{l}\text { Whānau: } \\
\text { Interdependence and } \\
\text { connectedness }\end{array}$ & $\begin{array}{l}\text { Motivation: } \\
\text { Inspiration and drive }\end{array}$ & $\begin{array}{l}\text { Demeanour: } \\
\text { Appearance and body language }\end{array}$ & $\begin{array}{l}\text { Cultural identity: } \\
\text { Pride and security }\end{array}$ \\
\hline & $\begin{array}{l}\text { Whenua: } \\
\text { Kinship and belonging }\end{array}$ & $\begin{array}{l}\text { Emotions: } \\
\text { Thoughts and feelings }\end{array}$ & $\begin{array}{l}\text { Energy levels: } \\
\text { Alertness and zeal }\end{array}$ & $\begin{array}{l}\text { Attitude and spirit: } \\
\text { Manner and disposition }\end{array}$ \\
\hline & $\begin{array}{l}\text { Friendships: } \\
\text { Co-operation and empathy }\end{array}$ & $\begin{array}{l}\text { Cognition: } \\
\text { Learning and understanding }\end{array}$ & $\begin{array}{l}\text { Physical safety: } \\
\text { Respect for self and others }\end{array}$ & $\begin{array}{l}\text { Resilience: } \\
\text { Courage and confidence }\end{array}$ \\
\hline
\end{tabular}

\begin{tabular}{|c|c|}
\hline Domain & Reflective questions \\
\hline $\begin{array}{l}\text { Hononga: } \\
\text { Relational aspects ... within the } \\
\text { whānau and with others } \\
\text { Consider how the programme plan } \\
\text { will support and strengthen social } \\
\text { relationships }\end{array}$ & $\begin{array}{l}\text { - How strong are his whānau relationships ... his connectedness to his whānau? } \\
\text { - How strong are his connections to/relationships with others (whānau whanui, hapū, iwi ...)? } \\
\text { - How is his position in the whānau being acknowledged (i.e.: the eldest, youngest, only son ...)? } \\
\text { - How strong are his connections to/relationships with places (papa kainga, marae, whenua ...)? } \\
\text { - Whānau whanui ... how might wider whānau contribute or feature? } \\
\text { - How strong (positive) are his relationships with key others (peers, teachers ...)? }\end{array}$ \\
\hline $\begin{array}{l}\text { Hinengaro: } \\
\text { Psychological aspects ... thoughts } \\
\text { and feelings, learning } \\
\text { Consider how the programme } \\
\text { plan will uplift and strengthen the } \\
\text { thoughts and feelings }\end{array}$ & $\begin{array}{l}\text { - What are the things that inspire and motivate him? } \\
\text { - How does he display/express his emotions (verbally, nonverbally)? } \\
\text { - How respectful is he of others' thoughts and feelings? } \\
\text { - Does he understand what others are communicating to him? } \\
\text { - How is all of this affecting his engagement/his participation in activities at school? } \\
\text { - How is all of this affecting his learning and achievement? }\end{array}$ \\
\hline $\begin{array}{l}\text { Tinana: } \\
\text { Physical aspects ... demeanour, } \\
\text { physical health and wellbeing } \\
\text { Consider how the programme plan } \\
\text { will enhance physical health and } \\
\text { wellbeing ... }\end{array}$ & $\begin{array}{l}\text { - How is his "āhua" (his demeanour, his appearance)_how does he "look"? } \\
\text { - What messages might he be expressing with his body language? } \\
\text { - What are his energy levels like? } \\
\text { - How alert is he? } \\
\text { - } \quad \text { Is he others respecting his personal space? }\end{array}$ \\
\hline $\begin{array}{l}\text { Mana Motuhake: } \\
\text { Self-concept ... cultural identity, } \\
\text { attitude, belonging } \\
\text { Consider how the programme plan } \\
\text { will strengthen and enhance identity } \\
\text { and overall wellbeing }\end{array}$ & $\begin{array}{l}\text { - How is his cultural identity being supported and strengthened by others (school, peers)? } \\
\text { - How is meaning derived from his name? } \\
\text { - How is his self-concept affecting his attitude-i.e., his responses to others, his manner, his outlook? } \\
\text { - How might his attitude/spirit (his mana) be enhanced and uplifted? } \\
\text { - What opportunities are being provided which enable him to make positive choices? } \\
\text { - How can he be supported to build his confidence and strengthen his resilience? }\end{array}$ \\
\hline
\end{tabular}




\section{MĀORI ACHIEVEMENT}

According to Rutherford (2004), developing these interconnected areas of skill and expertise is seen as central for successful learning throughout life.

Macfarlane et al. (2008) describe five compelling cultural constructs from within a Māori world view that highlight Māori traditional understandings of human development and learning and teaching (pedagogy). These five cultural constructs-known collectively as He Tikanga Whakaaro (Grace, 2005)_-are aligned and compared with the five key competencies in The New Zealand Curriculum (Ministry of Education, 2007) in Table 2.

\section{TABLE 2 COMPARISON BETWEEN THE KEY COMPETENCIES (MINISTRY OF EDUCATION, 2005) AND HE TIKANGA WHAKAARO (GRACE, 2005)}

\begin{tabular}{|l|l|}
\hline \multicolumn{1}{|c|}{ Key } & \multicolumn{1}{|c|}{ He Tikanga Whakaaro } \\
\hline $\begin{array}{l}\text { 1. Thinking } \\
\text { 2. Making } \\
\text { meaning }\end{array}$ & $\begin{array}{l}\text { 1. Tātaritanga: thinking and making } \\
\text { meaning; thinking, problem solving and } \\
\text { having a commitment to supporting the } \\
\text { group }\end{array}$ \\
\hline $\begin{array}{l}\text { 3. Relating to } \\
\text { others }\end{array}$ & $\begin{array}{l}\text { 2. Manaakitanga: a context of caring } \\
\text { relationships }\end{array}$ \\
\hline $\begin{array}{l}\text { 4. Managing } \\
\text { self }\end{array}$ & $\begin{array}{l}\text { 3. Rangatiratanga } \\
\text { 4. Whanaungatanga } \\
\text { Taking responsibility for, and control } \\
\text { over, one's own learning, whereby } \\
\text { individual agency is accorded by } \\
\text { belonging to a group }\end{array}$ \\
\hline $\begin{array}{l}\text { 5. Participating } \\
\text { and } \\
\text { contributing }\end{array}$ & $\begin{array}{l}\text { 5. Whaiwāhitanga: attaining a sense } \\
\text { of space and place within the general } \\
\text { scheme of things }\end{array}$ \\
\hline
\end{tabular}

Four of the cultural constructs were further aligned with the four component interventions that underpin the 2007 Effective Interventions for Behavioural Challenges (EIBC) professional learning and development programme. This programme was developed by Professor Luanna Meyer (Victoria University of Wellington) for use by Ministry of Education, Special Education. The four component interventions are:

- ecological components

- cognition skills

- replacement skills

- functionality skills.

The key competency components of He Tikanga

Whakaaro comprise the treaty principle of participation within Te Pikinga ki Runga. They serve to reiterate the significance of the learning environment (context and content) being inclusive of - and responsive to-the needs of the tamaiti.

\section{Applying Te Pikinga ki Runga: Case study}

Tyrone is an eight-year-old Māori boy, in a Year 4 class in an urban primary school. His behaviour is causing his teacher increasing concern, specifically in terms of his personal safety.

Tyrone is the third of five children who all live at home with both of their birth parents. Tyrone's nana (who lived with the family since Tyrone was born) died a year ago of a brain tumour. He was very close to her and misses her immensely. Following his nana's death, the whānau moved from their wider whānau and rural marae into the nearby city. They sometimes return for visits and spend time with the wider whānau and at their marae.

A shy, withdrawn and anxious boy, Tyrone frequently absconds from school in a highly agitated and aroused state-and for no apparent reason. His father brings him to school daily, and Tyrone has to be restrained so that his father can leave. Tyrone refuses to speak to anyone at school (apart from one boy) and often cries for up to an hour if asked to participate in verbal activities. He has previously been in receipt of Resource Teacher Learning and Behaviour support and was recently referred to the Ministry of Education, Special Education for further intervention.

The teacher reports that Tyrone is accomplished at drawing and art, and also loves reading and maths. $\mathrm{He}$ has one special friend (Kepa) who looks after him and who speaks for him: Tyrone occasionally whispers things to Kepa. Tyrone is not bullied at school-his peers appear to like him. He has many long absences from school, and this is now affecting his learning.

- Because of the stress that this is causing the family, Tyrone's parents have started keeping him at homesometimes for up to two weeks.

- The school is never informed about these long absences.

- Tyrone's mother is no longer working due to a recent accident where she was knocked from her push-bike and sustained a minor head injury.

- Tyrone is quite vocal at home.

How will the classroom teacher and special education practitioner respond to this situation? How could they apply the treaty components of Te Pikinga ki Runga, in order to make meaning of (assess and analyse), and respond to (programme plan), the situation? 


\section{MĀORI ACHIEVEMENT}

\section{The principle of participation}

The teacher and special education practitioner realised that they needed to build a closer relationship with Tyrone's parents so that they could gain their trust and support and work more closely as a team. They realised that they had never met as a group at any stage, to share collective thoughts, aspirations or concerns. Communication between the school and whānau had only ever been "one-way communication", in other words, via a home-school notebook when there was something negative to report about Tyrone, or by phone if the school urgently required his father to help find Tyrone when he had absconded from the school grounds.

The school had not shared anything positive about Tyrone with the whānau-even though there had been many opportunities to do so. It was therefore agreed that the school would initiate a team meeting with the whānau immediately, so that both parties could begin to build closer working relationships, share thoughts, start collaborating and co-constructing specific strategies, and to also determine how a two-way communication process could support everyone more effectively.

\section{The principle of protection}

Under the principle of protection, the teacher and special education practitioner drew on the Te Huia grid and prompt questions to identify which of the holistic domains needed further understanding and support, and also where there were strengths and opportunities for success. A great deal of information had been shared by the whānau during the initial meeting which informed this process.

(a) The hononga (relational) domain: the teacher and special education practitioner realised that Tyrone was actually suffering from severe trauma. During the school day he was continuously worried about his mother, fearing that she would die (just like his nana had) because of the nature of her head injury. Throughout the school day his fear and anxiety would increase until he could no longer bear it. It also became clear that Tyrone (and the whole whānau) was missing extended whānau and their marae - an area that the whānau was going to focus on addressing.

(b) The tinana (physical) domain: it was obvious to the teacher and school staff that Tyrone's outward demeanour at school was indicative of his high levels of inner tension and fear, which was resulting in his absconding behaviour (a serious physical-safety issue) as well as his choosing not to speak at school (a barrier to his potential success at school).

(c) The hinengaro (psychological) domain: it was noticeable to the teacher and special education practitioner that Tyrone was holding in his most worrying thoughts, feelings and fears, which was obviously causing him a great deal of trauma during the school day. Tyrone also had many cognitive strengths and abilities that could be used as opportunities to enhance his attitude and spirit, both at school and at home.

(d) The mana motuhake (self-concept) domain: it was apparent to the teacher and special education practitioner that Tyrone was feeling sad and scared for almost all of the school day-which was severely affecting his selfconfidence, his attitude towards others and his ability to participate in the school curriculum.

\section{The principle of participation}

The teacher and special education practitioner realised that all of the He Tikanga Whakaaro competencies needed to be focused on in order to support Tyrone in the classroom.

(a) They realised that the manaakitanga/ecological components needed to be a target so that Tyrone felt supported and safe in the classroom.

(b) They realised that they needed to focus on the tātaritanga/cognition-skills area so that Tyrone would feel assured and understand that his mother was safe; he needed to process this information without fear.

(c) They realised that Tyrone needed regular opportunities to express rangatiratanga/replacement skills, so that he could safely manage himself when he started to feel anxious during the school day.

(d) They realised that they needed to increase and extend opportunities for Tyrone to display whaiwāhitanga/ functionality skills at school by enabling him to participate and contribute in the areas that he most enjoyed and felt successful doing.

In summary, the following goal and set of strategies were agreed to by all parties:

Goal: To alleviate Tyrone's trauma and anxiety during the school day so that he is able to participate and function fully and positively.

Strategies:

- Tyrone's father would stay on at school with him for a longer period in the morning to enable him to settle into class (decreasing over time).

- Tyrone would have access to a specific number of "phone cards" each day, which he could cash in to ring his mother at selected intervals (reducing over time).

- Tyrone's mother would explain to him that she was not at risk of dying; it was agreed that she would take Tyrone to her doctor so they could talk about that.

- Tyrone would have a personalised learning plan which focused on his strengths and preferences.

- Tyrone would be encouraged to continue exploring art as a medium for expressing his thoughts and feelingsboth at school and at home. 


\section{MĀORI ACHIEVEMENT}

- Kepa would remain Tyrone's "mouthpiece".

- The school and whānau would maintain regular and positive communication that involved and included Tyrone.

- There would be a weekly debrief at school each Friday lunchtime over shared kai. This debrief would include Tyrone, his parents, Kepa, the class teacher, the special education practitioner and the principal. The focus of this debrief would be to monitor progress, capture and report on positive gains and to modify the strategies as required.

- Tyrone and his whānau would schedule regular trips home to the extended whānau and marae.

\section{Conclusion}

In the field of mainstream and special education research and practice, Western theories and knowledge have been viewed for many years as the conventional and acceptable sources from which to draw. While many of these sources have been, and still are, adroit and effective for making a difference in identification, assessment and programme planning for students with special needs, they can run the risk of homogenising practice and, as a consequence, potentially marginalising a significant sector of the student population because the types of interventions that are being constructed may not be the most responsive.

Cultural dimensions within education regularly pose challenges for many education practitioners because they are so value laden. Conventional approaches regularly subjugate cultural aspects as these aspects are not perceived to be in tandem with "the norm". There appears to be increasing awareness that the dominant culture both determines and provides the professional delivery, even though the minority culture increasingly provides the students.

By selecting the noted and the proven in Māori literature, and by listening to the voices of Māori and non-Māori practitioners as they share their experiences in a culturally responsive way, Te Pikinga ki Runga encourages educational practitioners to convert theory into practice. The framework propounds that behaviour that is seen in one culture may also be found in others, yet it may bear a completely different significance in that culture. This suggests that there is a need to go beyond strictly educational or psychological approaches, and into a more culturally grounded approach. For mainstream and special education practice this means delving into the concepts and thinking that characterise models such as $T e$ Whäriki (Ministry of Education, 1996), Te Wheke and Te Whare Tapa Whā, and deriving meaning from their convictions so as to inform practice.

The subject of responding effectively to behavioural challenges in the context of Māori students and their whānau has tested educators for many years. The challenge is compounded by many factors, not least of which is the dearth of trained professionals who are Māori. Te Pikinga ki Runga is a response to this challenge. Underpinned by the principles of the Treaty of Waitangi, appreciative of the impact of engaging with the home environment, responsive to the holistic wellbeing of the tamaiti and cognisant of the competencies that teachers wish to promote in the classrooms, this framework seeks to untangle some of the intricacies for educators in their work with Māori students, and indeed with all students and their whānau.

\section{References}

Bevan-Brown, J. (2001). Evaluating special educational services for learners from ethnically diverse groups: Getting it right. Journal of the Association for Persons with Severe Handicaps, 26, 138-147.

Bevan-Brown, J. (2003). The cultural self review: Providing culturally effective, inclusive, education for Māori learners. Wellington: New Zealand Council for Educational Research.

Bishop, R., \& Glynn, T. (1999). Culture counts: Changing power relations in education. Palmerston North: Dunmore Press.

Blampied, N. M. (1999). Issues in teaching Health Psychology in Aotearoa/New Zealand. Bulletin of the New Zealand Psychological Society, 97, 41-45.

Brewerton, M. (2004). Reframing the essential skills: Implications of the OECD Defining and Selecting Key Competencies Project: A background paper prepared for the Ministry of Education. Wellington: Ministry of Education.

Durie, M. (1994). Whaiora: Māori health development. Auckland: Oxford University Press.

Durie, M. H. (1998). Te mana, te kawanatanga: The politics of Māori sovereignty. Auckland: Oxford University Press.

Durie, M. (1999). Te Pae Mahutonga: A model for Māori health promotion. Health Promotion Forum of New Zealand Newsletter, 49, 2-5.

Evans, I., Fitzgerald, J., Harvey, S., \& Herbert, A. (2008, July). Cultural competencies for complex systems (family, school, and community): Perspectives on training clinical child psychologists in Aotearoa New Zealand. In B. Anton (Chair), International perspectives on professional training for clinical child and adolescent psychologists. Symposium conducted at the International Congress of Psychology, Berlin.

Glynn, T., Berryman, M., Walker, R., Reweti, M., \& O’Brien, K. (2001, July). Partnerships with indigenous people: Modifying the cultural mainstream. Paper presented at the Partnerships in Education Psychology conference, Brisbane. 


\section{MĀORI ACHIEVEMENT}

Grace, W. (2005, November). He māpuna te tamaiti: Māori ecologies to support the child. Paper presented to the Commentary Group on the New Zealand Curriculum Framework Key Competencies, commissioned by the Ministry of Education, Wellington.

Hambleton, R. K. (2001). The next generation of the ITC test translation and adaptation guidelines. European Journal of Psychological Assessment, 17(3), 164-172.

Herbert, A. M. L. (2002). Bicultural partnerships in clinical training and practice in Aotearoa/New Zealand. New Zealand Journal of Psychology, 31, 110-116.

Irwin, J. (1984). An introduction to Māori religion: Its character before European contact and its survival in contemporary Māori and New Zealand culture. Bedford Park, SA: Australian Association for the Study of Religions.

Kingi, T. K., \& Durie, M. H. (2000). Hua Oranga: A Māori measure of mental health outcome. Palmerston North: School of Māori Studies, Massey University.

Macfarlane, A. (1998, July). Piki ake te tikanga: Culture counts in special education. Paper presented at the 28 th annual conference of the Australian Teacher Education Association, Melbourne.

Macfarlane, A. (2005). Inclusion and Māori ecologies: An educultural approach. In D. Fraser, R. Moltzen, \& K. Ryba (Eds.), Learners with special needs in Aotearoa New Zealand (3rd ed., pp. 99-116). Melbourne: Thomson Dunmore Press.

Macfarlane, A., \& Macfarlane, S. (2008, October). A synthesis of culturally inclusive approaches in special education: From research to practice. Paper presented at the Education Plus Professional Development Forum, College of Education, University of Canterbury, Christchurch.

Macfarlane, A., Blampied, N., \& Macfarlane, S. (2009). A blending of streams in psychology. Manuscript submitted for publication.

Macfarlane, A., Glynn, T., Grace, W., Penetito, W., \& Bateman, S. (2008). Indigenous epistemology in a national curriculum framework? Ethnicities, 8(1), 102-127. London: Sage.

Meyer, L. H. (2003). Wanted: Internationally appropriate best practices. Research and Practice for Persons with Severe Disabilities, 28, 33-36.

Meyer, L. (2007). Effective Interventions for Behavioural Challenges: A professional learning and development programme for special education practitioners. Wellington: University of Victoria.
Ministry of Education. (1996). Te whāriki: He whāriki mātauranga mō ngā mokopuna o Aotearoa: Early childhood curriculum. Wellington: Learning Media.

Ministry of Education. (2005). Key competencies: The New Zealand Curriculum/Marautanga Project. Wellington: Learning Media.

Ministry of Education. (2007). The New Zealand curriculum. Wellington: Learning Media.

Ministry of Education. (2008). Ka hikitia: Managing for success: The Māori education strategy 2008-2012. Wellington: Author.

Ministry of Education, Special Education. (2006). Specialist Service Standards. Retrieved from http:// www.minedu.govt.nz/ /media/MinEdu/Files/ EducationSectors/SpecialEducation/AboutSpecialEd/ SpecialistServiceStandards.pdf

Nikora, L. (2007). Māori social identities in New Zealand and Hawai'i. Unpublished doctoral thesis, University of Waikato.

Pere, R. (1991). Te wheke: A celebration of ultimate wisdom. Gisborne: Ao Ako Global Learning New Zealand.

Rutherford, J. (2004, December). Key competencies in the New Zealand curriculum: A snapshot of consultation. Wellington: Ministry of Education.

Tajfel, H. (1981). Human groups and social categories: Studies in social psychology. Cambridge, UK: Cambridge University Press.

Tajfel, H., \& Turner, J. C. (1986). The social identity theory of intergroup behaviour. In S. Worchel \& W. Austin (Eds.), Psychology of intergroup relations (2nd ed., pp. 7-24). Chicago: Nelson-Hall.

van de Vijver, F., \& Hambleton, R. K. (1996). Translating tests: Some practical guidelines. European Psychologist, 1, 89-99.

SONJA MACFARLANE (Ngāi Tahu; Ngāti Waewae) is Pouhikiahurea/Practice Leader: Services to Māori for the Ministry of Education, Special Education. A former teacher, her work focuses on strengthening professional practice and service delivery for tamariki and whānau. 